\title{
Cherries: Calendar of Operations for Home Gardeners
}

\author{
Pamela M. Geisel is UC Cooperative Extension Farm Advisor in Environmental Horticulture for \\ Fresno County; Carolyn L. Unruh is UCCE staff writer for Fresno County; and Paul Vossen is \\ UCCE Farm Advisor in Fruits, Vegetables, and Marketing for Sonoma and Marin Counties.
}

Cherry trees are best suited to moderate climate regions in California, and most varieties require at least 600 hours of winter chilling (below $45^{\circ} \mathrm{F}$ ) for normal flowering and consistent production. High summer temperatures contribute to fruit deformities such as doubling or spurring of the fruit, although some varieties are more tolerant of high temperatures. In foggy or very cool climates, fruit disease problems make production of quality fruit difficult. Generally speaking, sour cherries are more likely than sweet cherries to produce good-quality fruit in the warmer climate zones of California.

Cherries need well-drained soil because they are quite prone to root and crown rots, especially in heavier-textured soils. They generally do not do well when planted in lawns: frequent irrigations promote root diseases to which cherries are susceptible. Many cherries are not self-fruitful and so require a pollenizer to ensure a good crop. A second compatible variety has to be planted nearby or grafted onto one major limb of the cherry tree.

\section{Winter Dormant Season}

1.If scale insects, aphids, or mites are recurring problems, apply dormant oil sprays (follow label instructions) to help control these pests.

2.Prune out about 10 percent of last year's growth on mature trees to let light into the tree. Remove broken and diseased branches.

3.Cherry trees sunburn easily. In hot regions, apply a 1:1 mixture of white interior latex paint and water for protection from sunburn and subsequent borer infestation. Apply the paint mixture from two inches below the soil surface up the entire trunk and on southwest-exposed scaffold branches.

4.Plant new trees during the dormant season in areas that have good soil texture and good drainage. Avoid planting in heavy or compacted soils.

\section{Spring Bloom Season}

1.You may need to apply fungicide to control brown rot. Apply bordeaux or fixed copper at the popcorn stage of bud development (when the unopened flower buds have matured and the petal color is discernible, so they resemble partially popped corn kernels). Apply again at the full-bloom stage, following label instructions.

2.Keep the trunk and the soil at the base of the tree dry during irrigation. Apply water out toward the drip line to reduce crown rot problems.

\section{Spring Harvest Season}

1.If you use drip irrigation, apply just the amount of water needed to replace what is used by the tree and lost from the soil through evaporation. If you use sprinkler or flood irrigation, water about every two to three weeks and provide enough water to wet the soil to a depth of 18 to 24 inches. During summer, young, small trees will need about 4 to 12 gallons of water per day, and large trees up to 250 gallons per week, although water requirements will vary depending on environmental conditions and your soil type.

2. Cover trees with netting to protect the fruit from birds.

3.Harvest cherries when fully ripe, and avoid damaging the fruit spurs as the fruit is picked. Keep the stems attached to the cherries to keep tearing of the flesh to a minimum. Cherries may be stored for several days under refrigeration. They may be sun-dried, canned, or frozen for longer storage.

4.Apply nitrogen fertilizer after harvest. Water the fertilizer in immediately to avoid loss of nitrogen. For mature trees, use about 4 pounds of ammonium sulfate annually.

\section{Summer and Autumn}

1.Continue regular irrigation until fall rains and cold weather arrive.

2.Avoid excessive cultivation around the tree as it may damage shallow roots and expose them to disease organisms. 


\section{For More Information}

Cousult these UC IPM Pest Notes online at http: / / www.ipm.ucdavis.edu:

Aphids

Bordeaux Mixture

Scales

Spider Mites

You'll also find detailed information on many aspects of fruit and nut tree care in these titles and in other publications, slides sets, and videos from UC ANR:

California Master Gardener Handbook, publication 3382

Drip Irrigation in the Home Landscape, publication 21579

Pests of the Garden and Small Farm, publication 3332

Pruning Fruit and Nut Trees, publication 21171

Sweet Cherries for the Home Grounds, publication 2951

The UC Guide to Solving Garden and Landscape Problems, CD-ROM 3400

\section{ORDERING}

To order these products, visit our online catalog at http: / / anrcatalog.ucdavis.edu. You can also place orders by mail, phone, or fax, or request a printed cata$\log$ of publications, slide sets, and videos from

University of California

Agriculture and Natural Resources

Communication Services

6701 San Pablo Avenue, 2nd Floor

Oakland, California 94608-1239

Telephone: 800-994-8849 or 510-642-2431

FAX: 510-643-5470

E-mail inquiries: danrcs@ucdavis.edu

For a free catalog of other publications, telephone (800) 994-8849.

Visit the ANR Communication Services website at http:/ / anrcatalog.ucdavis.edu.

\section{Publication 7260}

(C) 2002 by the Regents of the University of California, Division of Agriculture and Natural Resources. All rights reserved.

The University of California prohibits discrimination against or harassment of any person employed by or seeking employment with the University on the basis of race, color, national origin, religion, sex, physical or mental disability, medical condition (cancer-related or genetic characteristics), ancestry, marital status, age, sexual orientation, citizenship, or status as a covered veteran (special disabled veteran, Vietnam-era veteran or any other veteran who served on active duty during a war or in a campaign or expedition for which a campaign badge has been authorized).

University Policy is intended to be consistent with the provisions of applicable State and Federal laws. Inquiries regarding the University's nondiscrimination policies may be directed to the Affirmative Action/Staff Personnel Services Director, University of California, Agriculture and Natural Resources, 300 Lakeside Drive, 6thFloor, Oakland, CA 94612-3550; 510-987-0096. For information on how to obtain this publication and other ANR CS products, call 800-994-8849. 


\section{WARNING ON THE USE OF CHEMICALS}

Carefully follow all precautions and safety recommendations given on the container label. Store all chemicals in their original labeled containers in a locked cabinet or shed, away from foods or feeds, and out of the reach of children, unauthorized persons, pets, and livestock.

Confine chemicals to the property being treated. Avoid drift onto neighboring properties, especially gardens containing fruits and/or vegetables ready to be picked.

Mix and apply only the amount of pesticide you will need to complete the application. spray all the material according to label directions. Do not dispose of unused material by pouring down the drain or toilet. Do not pour on ground: soil or underground water supplies may be contaminated. follow label directions for disposing of container. Never burn pesticide containers.

PHYTOTOXICITY: Certain chemicals may cause plant injury if used at the wrong stage of plant development or when temperatures are too high. Injury may also result from excessive amounts or the wrong formulation or from mixing incompatible materials. Inert ingredients, such as wetters, spreaders, emulsifiers, diluents, and solvents, can cause plant injury. Since formulations are often changed by manufacturers, it is possible that plant injury may occur, even though no injury was noted in previous seasons.

Funding for this publication was made possible through a grant from the Elvenia J. Slosson Fund. 